UDC 94 (477.53) «1937-1938»

DOI: 10.24919/2519-058x.11.170702

\title{
Iryna PETRENKO
}

PhD hab. (History), Professor, Head of the Department of Pedagogy and Social Sciences, Poltava University of Economics and Trade, 3 Kovalya Street, Poltava, Ukraine, postal code 36014 (poonsku@ukr.net)

ORCID: https://orcid.org/0000-0002-2994-3833

Researcher ID: B-5310-2019 (http://www.researcherid.com/rid/B-5310-2019

\section{Oleksandr LOSHCHYKHIN}

Phd hab. (Law), Professor, Merited Economist of Ukraine, Professor of the Department of Constitutional and International Law Educational and Scientific Humanitarian Institute Taurida National V. I. Vernadsky University, 33 I. Kudri Street, Kyiv, Ukraine, postal code 01042 (loshihin@podol.net)

ORCID: https://orcid.org/0000-0001-9689-1650

Researcher ID: D-2251-2019 (http://www.researcherid.com/rid/D-2251-2019)

\section{Ірина ПЕТРЕНКО}

доктор історичних наук, професор, завідувач кафедри педагогіки та суспільних наук ВНЗ Укоопспілки «Полтавський університет економіки і торгівлі», вулиця Коваля, 3, м. Полтава, Україна, індекс 36014 (poonsku@ukr.net)

\section{Олександр ЛОЩИХІН}

доктор юридичних наук, професор, Заслужений економіст Украӥни, професор кафедри конституиійного та міжнародного права Навчально-наукового гуманітарного інституту Таврійського національного університету імені В. І. Вернадського, вулиия I.Kyдpi, 33, м. Київ, Украӥна, індекс 01042 (loshihin@podol.net)

Бібліографічний опис статті: Petrenko, I. \& Loshchykhin, O. (2019). German colonies in Poltava Region. Skhidnoievropeiskyi istorychnyi visnyk [East European Historical Bulletin], 11, 78-88. doi: 10.24919/2519-058x.11.170702

\section{GERMAN COLONIES IN POLTAVA REGION}

Summary. The purpose of the research is to analyze the preconditions and the circumstances of the settlement of the German colonists in Poltava region; to reveal the role of the ethnic Germans in the political, socio-economic and spiritual development of the region. The methodology of the research is based on the principles of historicism, systemicity, scientism, verification, the author's objectivity, as well as the use of general scientific (analysis, synthesis, generalization) and special-historical (historical-genetic, historical-typological, historical-systemic, historical and chronological) methods. The scientific novelty - on the basis of the published sources and the scientific works, the reasons, the preconditions for the emergence of the German settlers in Poltava region have been determined; their role in the political, economic, social, cultural and spiritual life of the region has been highlighted; the contribution of the people of German nationality to the Russian army and health care in the first half of the XIXth century has been researched. Conclusions. The revealed documents and the literary sources, despite their scarcity, still allow us to analyze the life 
and the activities of the German colonies in Poltava region. The settlement of Poltava region by the German settlers took place in the context of the general-imperial resettlement policy of the Russian government in the late XVIIIth - the early XIXth century with the corresponding imperial tendencies. The Germans-settlers, who arrived in Poltava region on the invitation of the duke Olexiy Kurakin, made a lot for the development of the region. Thanks to them, the sheep breeding developed at a very high pace, because the Russian army and the fleet, and the construction industry were provided with a good quality cloth. The Germans-settlers began the development of the landed feudal factories, taught and prepared many masters for them. With the genesis of the bourgeois relations in the Russian Empire, the construction of the large factories with the significant capital and machines for the manufacture of cloths, a hand-made production of the German weaving settlers was not on time. They worked hard, but this work did not bring the desired profits and did not allow them to have a good life. That fact explains the reduction of such «home factories» of the German settlers, and hence the reduction of the masters-workers. The reduction subsequently led to the elimination of these small enterprises. The German settlers in Poltava region had their own special socio-economic characteristics: a significant potential and the propensity to entrepreneurship, wealth, responsibility, honesty in business. The economic development of the colonies depended on the raw materials, the skills of the settlers, and the relations with the local authorities.

Key words: German colonies, Poltava region, Ukraine, Russian Empire, duke Olexiy Kurakin, village of Khreschatyk.

\section{НІМЕЦЬКІ КОЛОНІЇ НА ПОЛТАВЩИНІ}

Анотація. Мета дослідження проаналізувати передумови та обставини поселення німців-колоністів на Полтавщині; розкрити роль етнічних німців у політичному, соціально-економічному і духовному розвитку краю. Методологія досліджсення спирається на принципи історизму, системності, науковості, верифікації, авторської об'єктивності, а також на використання загальнонаукових (аналіз, синтез, узагальнення) та спеціально-історичних (історико-генетичний, історико-типологічний, історико-системний, історико-хронологічний) методів. Наукова новизна полягає у тому, щзо на основі опублікованих джерел й наукових праџь з'ясовано причини $і$ передумови появи німецьких поселениів на території Полтавщчини; з'ясовано їх роль у політичному, економічному, сочіальному, культурному та духовному житті краю; досліджено внесок людей німецької національності у забезпечення російської армї̈у першій половині ХІХ ст. та охороні здоров'я. Висновки. Виявлені документальні та літературні джерела, незважаючи на їх нечисленність, все ж дають змогу проаналізувати життя $і$ діяльність німещьких колоній на Полтавщчні. Заселення полтавського краю німецькими поселениями відбулося у контексті загальноімперської переселенської політики уряду Росії наприкінці XVIII - на початку XIX cm. з відповідними імперськими тендениіями. Німиі-поселенці, які прибули на Полтавщчину за запрошенням князя Олексія Куракіна, багато зробили для розвитку краю. Завдяки їм особливо високими темпами розвивалося вівчарство, адже якісною тканиною забезпечувалися російська армія $і$ флот, будівельна галузь. Німці-колоністи поклали початок розвитку поміщчцьких кріпосних фабрик, навчили і підготували багато майстрів для них тощуо. Із тенезою буржуазних відносин у Російській імперії, будівництвом великих фабрик зі значними капіталами та машинами для виготовлення сукон домашнє ручне виробництво німецьких ткачів-поселенців уже було не на часі. Вони тяжко працювали, але ияя робота вже не приносила бажаних прибутків і не давала можливості добре жити. Таким фактом $i$ можна пояснити скорочення таких «домашніх фабрик» німецьких поселенців, а відтак і майстрів у них, щзо згодом призвело до ліквідаџії цуих невеликих підприємств. Німецькі поселенці на Полтавщчині мали свої особливі сочіально-економічні характеристики: значний потенціал $і$ схильність до підприємницької діяльності, заможність, відповідальність, чесність у справах. Економічний розвиток колоній залежав від сировини, навичок поселенців, взаємовідносин із місиевою владою.

Ключові слова: німецькі колонї, Полтавщчина, Украӥна, Російська імперія, князь Олексій Куракін, селищее Хрещзатик.

Problem statement. The proclamation of Ukraine's independence in 1991 led to its development as a legal, democratic, sovereign and social state. Much attention was paid to ensuring the freedoms and rights of all citizens, regardless of the nationality, the religion, 
the culture, the race, etc. One of the important problems of Ukrainian state formation is to ensure a decent development of the national minorities, which in Ukraine are more than 100. Historically, many people of different nationalities lived and live in Ukraine, who, while not being ethnically Ukrainian, feel themselves the Ukrainians, although they preserve their own language, culture, traditions, religion.

The analysis of sources and recent researches. The history of the Germans-settlers in Poltava region was the subject of the scientific interest of the scientists. The basic scientific investigations were devoted to this issue by I. Pavlovskiy, V. Zhuk, A. Lushakova, O. Kovalenko, O. Kanienberh-Sandul, O. Ivanenko, J. Malitska, I. Shvaika, V. Volovyk and V. Yatsyuk, O. Zgurskyi, S. Meizus (Pavlovskiy, 1906, 1914 a, 1914 b; Zhuk, 2006; Lushakova, 2006; Kovalenko, 2013; Kanienberh-Sandul, 2018; Ivanenko, 2014; Malitska, 2017; Shvayka, 2016, 2018; Volovyk \& Yatsyuk, 2017; Zgurskyi, 2011; Meizus, 2019), etc. The researchers analyzed the reasons for the settlement of people of the German nationality in Poltava region, the conditions for their living and work, concluded the valuable contribution of the settlers to the development of Poltava region.

The publication's purpose is to analyze the reasons and features of the appearance of people of the German nationality in Poltava region; to reveal the role of the ethnic Germans in the political, socio-economic and spiritual development of the region.

Statement of the basic material. The first German colonies on the territory of the Left Bank of Ukraine appeared in the 60-ies of the XVIIIth century, during the reign of Catherine II in Russian Empire. In 1756 - 1766, the Germans-colonists, the farmers, the natives of Frankfurt am Main, were settled in the village of Khreschatyk, which then belonged to Lubny regiment (from 1872 - to Romny district of Chernihiv province, and from 1796 to Malorossiyska huberniya. Now Khreschatyk is located on the territory of Vedmezhivska village council of Romny district, Sumy region) (Zhuk, 2006, p. 11).

It is unknown how many German peasants arrived then in the Ukrainian lands, and, in particular, in Khreschatyk. There is the evidence that they were endowed with the land by the state and paid a land tax, that is, they belonged to the category of the state peasants. At the time of the 10th All-Russian Census of the Population in 1859, there were about 550 Germans-colonists of both sexes in Khreshchatyk (Bodianskyi, 1865, p. 245).

The Germans-artisans, military personnel, and other specialists are known in Kremenchuk from the second half of the XVIIIth century. The native inhabitants of the Dnieper town have long been engaged in various handicrafts. There were hoopers, wheel-makers, carriagemakers, saddlers (craftsmen of the production of finely tuned leather things, horse harnesses, belts, cases, gloves, etc.), blacksmiths, carpenters, boot-makers and the others. Since 1747 in the town there was a rope factory, as well as a brick, which produced more than 100 thousand bricks a year. In 1790 and 1794 two more tin plants were opened. From the ancient times, granite was used for the construction works, which was a lot in Kremenchuk area. At the beginning of the XIXth century the arrived German colonists made a significant contribution to the development of industry, especially the light one, in Poltava region, including Kremenchuk.

The first Germans-artisans in Poltava region appeared after Poltava became the center of Poltava province and Malorossiysky Governor-General. He was entrusted with the decree of Olexander I of February 27, 1802 «On the establishment of Malorossiyski provinces of Chernihiv and Poltava» (Pavlovskyi, 1914 b, p. 2; Poltava Governorate). Thus, Malorossiyska huberniya became Malorossiyska huberniya ruled by $t$ he governor-general with the 
provinces of Poltava and Chernihiv (Shandra, 2001, p. 64). These cardinal transformations envisaged a number of the significant planning and building changes. The main impact to it was the formation of a new administrative center and a massive administrative and housing construction.

Olexiy Kurakin, the Russian and Ukrainian statesman, the Governor-General of Malorossiya, the Duke, the member of the State Council, and Interior Minister of the Russian Empire, was actually called a manager in the system of the economic and military development, education, a social sphere, and the others. In order to provide the large-scale construction projects, the Governor-General of Malorossiya O. B. Kurakin invited some Germans-colonists, the specialists in brick-making, from Saratov province and he issued the order by which the landowners of the province were to send their serfs to Poltava for studying of brick-making. Until then, in Poltava there were not enough permanent brickmaking factories. At the end of the XVIIIth - the beginning of the XIXth century there were only two of them: one belonged to the «Poltava order of public indulgence» (Bilyi, 1974, p. 39), the second - to the Resurrection Church (Pavlovskiy, 1906, p. 72). Traditionally, if necessary, the temporary brick-making works were created, but those works could not provide the provincial construction projects with bricks because one master produced made about 500 bricks a day (Kovalenko, 2013, p. 211).

At the beginning of the XIXth century the Russian Empire, as well as various parts of the German lands, were threatened by the war with the French Emperor Napoleon. Therefore, there was a need to prepare for the war. The coal-metallurgical industry in the country expanded, and the light industry was dragging behind in its development, that is, there were not enough fabrics (cloth) in order to make a uniform for the Russian army soldiers. Previously, the cloth was purchased in the UK, but from the beginning of the XIXth century the trade and economic ties were broken because of the continental blockade of France. Such circumstances forced the development of its own textile industry. The Duke Olexiy Kurakin, having been for almost six years as the Governor-General of Malorossiya, studied the economy of the former Hetmanschyna well. He knew that there was a well-developed branch such as sheep-breeding in the region, the population produced a lot of a high-quality wool to make cloth (cloth). In order to organize the production of cloth at the state level, Olexiy Kurakin decided to invite professional cloth weavers from Germany (Pavlovskiy, 1914 b, p. 8).

According to the decree of Emperor Olexander I of June 20, 1808, the craftsmen from Bohemia, Moravia, Alsace, Saxonia and other western European lands were invited to accelerate the development of cloth-making in Russia. The Duke Olexiy Kurakin proposed to settle them in Poltava, Kremenchuk and Kostyantynohrad, at that time former Poltava huberniya province (German Colonies; About GP-PR).

He compiled a set of rights, duties and conditions of stay of the colonists in the province. The German settlers had privileges: they were guaranteed freedom of religion; they were free from duties and paying taxes for ten years, during the next ten years they had to pay a loan of $15-20$ kopicks for one tenth of the earth $(1 \mathrm{doz} .=1,09$ hec. $)$; in the rest duties the settlers were equated with the rest of the population; the exemption from a compulsory military service (the colonists were allowed to enter the civil service on condition of paying the debt to the treasury); the Germans could leave the colony or the state freely on condition of the debt repayment to the state and a three-year tax amount. The German settlers had the right to sell their products throughout the country freely. The state assisted them, giving the money 
on the road expenses and financed them during the settlement process (the so-called «fodder money») - 12 kopicks per person per day (Pavlovskiy, 1914, p. 201).

In fact, when moving from the border, the settlers from Bohemia, Moravia, Alsace, Saxonia and other German principalities were given a financial help - 10 kopicks a day for an adult and for 6 kopecks for every child a day. On the place of their arrival they received from 5 to 10 kopicks per person (Zhuk, 2006, p. 25).

To accommodate these artisans - the so-called «cloth manufacturers» - it was decided to build the houses in Poltava, Kremenchuk and Kostyantynohrad (now the city of Krasnohrad, Kharkiv region). According to the well-known Poltava historian of pre-revolutionary times I. F. Pavlovskiy, in November 1808 six families of first colonists, cloth and wool weavers came to Poltava. For their accommodation on the outskirts of the city, on the way to Yakivtsi, the provincial council redeemed 12 acres of land for 5287 rubles 96 kopicks by assignments and built about 50 houses. So there appeared a German settlement or colony. It was located in the area of the streets Fabrykantska (now - Balakina street) and Kolonistska (now Skovoroda street) and the adjacent lanes (Germans from Russia Settlement Locations).

The first large party of colonists reached Poltava in August 1809 - 130 people (with their families). They were accommodated in 16 houses. In some period of time, several more groups arrived. Thus, 54 families of the German colonists (249 people) settled in Poltava, 41 families (218 people) settled in Kostiantynohrad, 2 families (10 people) - in Kremenchuk. The administration often abuse its authority. Instead of 60 houses, planned for the colonists, only 53 were built before their arrival, and they were not completely ready (Pavlovskiy, 1914 a, p. 214)

The quality of these dwellings was, to say the least, low. Volodymyrkyi Governor, the Duke I. M. Dolhorukyi, who visited Poltava in 1810 and became acquainted with the colony's condition, left in his memoirs a record that it had made a very depressing impression on him. It is believed that the construction of this settlement and two more similar in Kremenchuk and Kostyantynohrad cost the treasury 400 thousand rubles. However, the houses were built from wood; in Poltava these «card houses» became real prisons for people. There were looms there, the whole family lived there too, and adults worked there as well, with the help of teenage children. The walls of the houses were «transparent», like a sieve, and during the work of the loom, they shook because they kept on the corners pillars. One family had to produce about 800 arshyns of cloth per year, using its own loom. For each arshyn, 82 kopicks were paid to the weavers, including the cost of raw materials; other expenses were not taken into account (Zhuk, 2006, p. 41). The severe working conditions, a poor nutrition often led to the disease of the colonists and their children. The medicines, like fuel, were given in debt. Ivan Saar, the head physician, treated for his patients exceptionally honest and selflessly.

In 1812, four colonists asked to let them go (that is, to quit) so that they could live and work in other cities (Kabuzan, 1976, p. 88). In 1816, The Duke Mykola Repnin was appointed a new Governor-General in Poltava and Chernihiv huberniya. According to his contemporaries he was a highly humane man and a good administrator, he loved the land where he worked, took care of the benefit of the entire population, defended the interests of people of serfdom, defended the still-surviving rights of the Cossacks. These factors are the main reason for the suspicion of separatism (Pamiatnaia knizhka, 1890, p. 16). M. Repnin was elected an honorary member of Kharkiv University, which was a rarity at that time for the administrators. So it is quite clear that the German colony immediately drew the attention of the Governor-General. He was thoroughly familiar with the working conditions and the 
material situation of its inhabitants, was convinced of the too difficult conditions of their lives and submitted a petition to the government.

In response to this petition, Olexander I ordered the Minister of the Interior Affairs to take such measures: to cancel all the debts of the colonists of the treasury; the state-owned houses in which they lived, to become their property with plots of land and hayfields; to give each family 100 rubles loans for 3 years; the state-owned tools to be owned by colonists; to allow the colonists to remain on the place or the Lutherans had the right to move to Poltava, and the Catholics - to Kostiantynohrad, without requiring the money for help; the communities were allowed to set up the courts on the analogy with other foreign colonies; to give each person the opportunity to do his own desired craft, regardless of the will of the chief. In pursuance of this decree, on May 13, 1820, the Governor-General issued a special instruction according to which the orders, the administrative-judicial authorities of the central government, were made for the management in the German settlements. They consisted of the headmistress (Schulz- in German) and two assessors (baisitzers), chosen by the community for a term of 3 years, and the clerk (Pysarevskyi, 1909, p. 45).

Such orders, the administrative-judicial authorities, were made in Poltava and Kostiantynohrad. All had to obey the headmistress (Shultz) and the assessors (baisitzers) unconditionally. The life in the colonies was carried out according to the rules developed on the initiative of the inhabitants themselves in 1815. The apprentices once a month gathered at the meeting, where they considered and discussed all their affairs. The weavers had their elders, who were chosen annually by all masters. 15 kopicks were taken from each at the meetings. For non-attendance at the meeting, the apprentices were fined: the first time for 10 kopicks, the second - for 20 kopicks, for non-payment they were excluded from the community. It was strictly forbidden to quarrel and offend each other, for the violation of these rules there was also a fine from 10 to 20 kopicks. The fine was also taken for appearance in a drunk or inappropriate form. The person, guilty of the fight, paid 50 kopicks, and if he could not pay, the apprentices informed the authorities and asked to punish the violator of the order (Pavlovskiy, 1914 a, p. 210). The members of the colony, who did not participate in the church liturgies all the year round (without distinction in religion) and did not join the performance of the sacred acts, were also severely punished. The criminal cases were heard in court.

The colonists were completely dependent on the administration. Without permission, nobody had the right to leave the settlement, to leave for a different city, even to marry. The administration also interfered in family affairs. A charity community took care of widows and orphans. The order tried to find a colonist to mary a widow in order to secure her and her children materially and not let the loom stop. Orphans were given to maintenance and upbringing.

Such rules seem, perhaps, quitestrict, but it should be said that the German clothmakers were noted for discipline, hard work, respectability in family relationships. The administration took care of their religious education (the Lutherans lived in Poltava mostly, the Catholics - in Kostiantynohrad). The law of 1818 changed the situation of the settlers; they became free craftsmen, could make the goods that they considered necessary to sell at affordable prices. Previously, they produced only cloth and supplied it to the treasury. Then the administration, through its commissioners, strictly observed that the colonists signed contracts with Kremenchuk Commissariat and other institutions, without making a cash deposit (Zhuk, 2006, p. 55). Now they could not get any order anywhere, they gave a deposit, 
and the made cloth and the other goods they sold themselves at fairs in Poltava, Romny or other cities, often with a loss to themselves.

At first, four factories appeared in Kremenchuh, where people of German origin were working. In 1809 the German colonist Helitser, having received from the state 10 thousand rubles of a ten-year subsidy, founded a factory for making fabrics (cloth). We can assume that the factory of an enterprising and energetic German made significant profits (Pavlovskiy, 1914 a, p. 3). Helitzer returned a government loan quickly, and in 1817 he had a desire to buy two houses for his compatriots. However, he got the refusal, because the law forbade the sale of houses that were allocated to the Germans-colonists with the country planes, even to their compatriots. On the map of Kremenchuk the cloth factory of Helitzer dates back to 1816 - 1832. In 1812 another German manufacturer, Rureht, received 10 thousand rubles from the state aid to create a factory for the production of leather goods. So, both the Germans, Helitzer and Rureht, were given land for the foundation of their enterprises. Rureht promised to produce more than 2 thousand skins in the first year of the factory work, and subsequently to increase the production to 10 thousand per year (Kabuzan, 1976, p. 37).

Thus, in Kremenchuk, thanks to the German masters, since the beginning of the XIXth century there were several small industrial enterprises that laid the foundations for the production of cloth, other fabrics, stockings, socks, high-quality leather and footwear. The colonists laid the foundation for educational institutions, in particular, the school for vocational education of youth was founded - Kremenchuk school factory.

Over the years, these enterprises have been developing, and the Ukrainianized descendants of the former Germans settlers worked with the Ukrainians and the representatives of other nationalities, for whom Kremenchuk became a home town. The colonists also contributed to the development of the machine-building industry.

In 1880, below the flow of the Dnieper River creek Kryvav Ruda, Orenstein, the Austrian, established his own leather factory (now a leather and fur factory) with almost the same number of workers. In 1888, in the city's outskirts Cherednychky the machine-building and the cast-iron plants of the Gebgold brothers appeared. There were employed more than 60 workers. There was also a small leather factory with a total of 5 employees (Lushakova, 2001, p. 194).

So representatives of the German nationality continued to develop industry in Kremenchuk. Already in the first half of the nineteenth century in the colonies, there were primary schools where children of weavers studied the Law of God, reading and writing. It is not exactly known about the time of the opening of a school in the German colony of Poltava, but in historical sources it is mentioned that when the settlers built the first church in 1832, then the German Florian exchanged a house for school and repaired it.

In 1831, at Kremenchuk Church the Lutheran School was founded (Ivanenko, 2014, p. 112). The funds for its maintenance were allocated constantly during its existence until the revolution of 1917.

Among the Germans, a fairly well-off stratum was allocated. The richest of them, Julian Leszek, produced up to 7,000 arshyns of cloth made from wool sheep greezed by him. For many years he headed the order of Poltava colonists. He died in 1853 and left some wealth. He made the testament and gave his children 15 thousand rubles only in the Odessa commercial bank. His wife, Anna Leshka, leased a cloth factory of the Khorol landowner Ivan Rodzianka. In Kostiantynohrad colony, Karl Treshau was considered to be the most prosperous (Zhuk, 2006, p. 41). From the mills of his factory, 300 arshyns of gray cloth, 
2000 arshyns of flannel, 500 arches of fables and 100 blankets were produced annually. His brother Gottfried Treshau produced much less goods. In general, the material condition of the ordinary Kostiantynohrad colonists was worse than in Poltava. At the time of the 10th AllRussian Census of the population in 1859 in Poltava, in the suburbs of the German colony, there were only 64 households with 1,098 inhabitants, of which 670 - men, 428 - women. The total sum of the representatives of the German nationality was 354 persons of both sexes (of the total population of the colony), 180 of them were engaged in the manufacture of the cloth. In Poltava district there lived 15 Germans (Nykolaichyk, 1891, p. 101).

By the beginning of the 1960 ies, as it has been mentioned above, from time to time, including during the past 10 years, the colonists were exempt from the tax by the Ministry of Finance, but in 1862 the Minister of Finance raised the issue of payingthe taxes. The German masters' request for the exemption from payment to the treasury was rejected. On the one hand, their financial position at that time significantly improved. On the other hand, in connection with the reforms carried out in the country, the government planned to approve the provisions on the abolition of the special situation of the colonists in order to equate them with the rights of all citizens of the empire - the bourgeois, the merchants, the peasants. In accordance with the provisions of the Committee of Ministers, approved by the Tsar on July 29 (August 10), 1866, all the «manufacturers» had to be registered, during the same year, not later than January 1 (13), 1867, in the urban or rural communities, without any new privileges in paying taxes and duties (Zhuk, 2006, p. 41). They were also allowed to leave the Russian Empire if they wished to. In this regard, Poltava community of colonists turned to the government with the houses and the land issue, signed by the landowners: whether they remain in their possession, as many Germans rebuilt their homes or built rather good new ones instead of the former old huts. In November 1866, the Germans concluded the second public «issue».

Having the opportunity to buy the land for cultivation on the outskirts of Poltava, they expressed their desire to be attached to the city community and to form their own special community, on the condition that the land in the colony be distributed equally between them. However, they asked to release them from recruitment until January 1 (13), 1867. On May 30 (June 11) 1867, the law came into force, which established the following: for clerical workers invited from abroad and the settled ones in Poltava hubernia to secure the right of the unlimited ownership of the property granted to them from the treasury in accordance with the royal decree of December 27, 1818; the supervision of the correct distribution of this property was given to the the committee, created to improve the position of the cloth manufacturers, settled in Poltava and Kostiantynohrad. At the time of the liquidation of the German colonies in Poltava hubernia, in Poltava city there lived 66 adult men, with women and children - 236 people (Pavlovskiy, 1914 a, p. 210).

By the order of Poltava Governor, Mykhailo Martynov, of December 31, 1867 (January $12,1868)$, the German colonies were closed. Over the years, the former German colony was built up with new buildings and changed its appearance.

It was too hard for the Germans to settle down in a foreign country under the new conditions, especially because of the negligence and dishonesty of many officials responsible for a colonial settlement, although the German weavers (called «cloth manufacturers») had some privileges. They formed separate groups of settlements that did not obey, as other strata, the national institutions, but had their own institutions: at first the inspection (until 1820), then the order and, finally (from the 40-ies of the XIXth century), the committee to which 
orders were subjected. But the Ministry of Internal Affairs of the Russian Empire did not care to create the human conditions of residence and work for the settlers, did not care to find an honest and skilled specialist who would be a specialist in this sphere and could control the work, would monitor the sale of products, so that the colonists were not fooled by the officials, the brokers-directors of raw materials and the purchasers of the manufactured goods.

Conclusions. Thus, the revealed documentary and literary sources, despite their scarcity, still allow us to analyze the life and the activities of the German colonies in Poltava region. The settlement of Poltava region by the German settlers took place in the context of the general-imperial resettlement policy of the Russian government in the late XVIIIth - the beginning of the XIXth century with the corresponding imperial tendencies.

The Germans-settlers, who arrived in Poltava region on the invitation of The Duke Olexiy Kurakin, made a lot for the development of the region. Thanks to them, sheep breeding developed at a very high pace, because the Russian army and fleet, and the construction industry provided a good quality cloth. The Germans, the colonists, began the development of the landed feudal factories, taught and prepared many masters for them, and others like that. With the genesis of bourgeois relations in the Russian Empire, the construction of large factories with a significant capital and machines for the manufacture of cloths home, manual production of German weaving settlers was not on time. They worked hard, but this work did not bring the desired profits and did not allow them to have a good life. That fact can be explained by the reduction of such «home factories» of the German settlers, and hence of their masters, which subsequently led to the elimination of these small enterprises. The German settlers in Poltava region had their own special socio-economic characteristics: a significant potential and propensity to entrepreneurship, wealth, responsibility, honesty in business. The economic development of the colonies depended on raw materials, the skills of settlers, and the relations with local authorities. On the basis of the analyzed data one can note a rather significant contribution of the representatives of the German nationality to the development of the material and spiritual culture of Poltava region, first of all, industry, construction, agriculture, medicine.

Perspectives of further research on this topic may be broadening of the source of the study, which will allow a thorough study of the contribution of well-known people of the German nationality to the development of Poltava region and Ukraine.

Acknowledgments. In addition, we would like to thank our teacher, a historian Vira Zhuk (1928 - 2008) for attracting attention to this topic, for the preparation of a ground-based research on the Germans-colonists and for the actualization of the study issue.

Funding. The authors received no financial support for the research, authorship, and/or publication of this article.

\section{BIBLIOGRAPHY}

About GP-PR. URL: http://grhs.org/chapters/gppr/about.html [in English].

Bilyi, P. Kh. (ed.) (1974). Poltavi 800 rokiv: 1174 - 1974.: zb. dokumentiv i materialiv [Poltava 800 years: 1174 - 1974. documents and materials.]. Kyiv: Naukova dumka, 420 p. [in Ukrainian].

Bodianskyi, P. (1865). Pamiatnaia knyzhka Poltavskoi hubernyy za 1865 hod. Poltava [Memorable book of the Poltava province for 1865]: Izd. Polt. Hub. Stat. Kom., 453 p. [in Russian].

German Colonies in the Poltava Province. URL: https://www.germansfromrussiasettlementlocatio ns.org/2019/02/german-colonies-in-poltava-province.html [in English].

Germans from Russia Settlement Locations. URL: https://www.germansfromrussiasettlementlocat ions.org/p/maps.html [in English]. 
Ivanenko, O. (2014). Nimtsi v kulturno-osvitnomu prostori Naddniprianskoi Ukrainy (druha polovyna XIX - pochatok XX st.) [The Germans in the cultural and educational space of the Dnieper Ukraine (the second half of the nineteenth and early twentieth centuries]. Ukrainskyi istorychnyi zhurnal-Ukrainian Historical Journal, 4, 109-127. [in Ukrainian].

Kabuzan, V. M. (1976). Zaselenye Novorossyy (Ekaterynoslavskoi y Khersonskoi hubernyi) $v$ XVII - pervoi polovyne XIX vekov (1719 - 1858) [The settlement of Novorossiia (Yekaterinoslav and Kherson provinces) in the XVIIth - the first half of the XIXth century (1719-1858)]. Moscow: Nauka, 307 p. [in Russian].

Kanienberh-Sandul, O. K. (2018). Pravove stanovyshche nimetskykh kolonistiv na Pivdni Ukrainy (kinets XVIII st. $-1917 r$ r) [The legal status of the German colonists in the South of Ukraine (end of the XVIIIth century - 1917)] (Extended abstract of Candidate's thesis). Odesa, 28 p. [in Ukrainian].

Kostiuk, M. P. (1998). Nimetska kolonizatsiia na Volyni (60-i roky XIX st. - 1914 r.) [German colonization in Volhynia (60s of the 19th century - 1914)] (Extended abstract of Candidate's thesis). Lviv, 18 p. [in Ukrainian].

Kovalenko, O. V. (2013). Pro stvorennia nimetskoi kolonii u Poltavi [About the creation of a German colony in Poltava]. Nimetski poselentsi na ukrainskykh zemliakh: istorychni ta aktualni problemy i perspektyvy: tezy mizhnarodnoi konferentsii, (pp. 211-214). Poltava. [in Ukrainian].

Lushakova, A. N., \& Evselevskyi, L. Y. (2001). Ulitsamy starogo Kremenchuga [The streets of the old Kremenchuk]. Kremenchuh: Kremenchuk, 222 p. [in Russian].

Lushakova, A. (2006). K 230-letyiu osnovanyia nemetskoi kolonyy v Kremenchuhe [To the 230th anniversary of the foundation of the German colony in Kremenchuk]. Visnyk Kremenchutskoho derzhavnoho politekhnichnoho universytetu. 37 (2), 11-15. [in Russian].

Maizus, S. (2019). «Nimetska koloniia»: ekskursiia tudy, de hrav Shchepkin [«German colony»: excursion to where Shchepkin played]. Rezhym dostupu: https://poltava365.com/1608-nimeczkakoloniya-ekskurs.html [in Ukrainian].

Malitska, J. (2017). Negotiating Imperial Rule: Colonists and Marriage in the Nineteenth-century Black Sea Steppe. Huddinge: Södertörns högskola, 392 p. [in English].

Nykolaichyk, F. D. (1891). Horod Kremenchug. Ystorycheskyi ocherk [Kremenchuk city. Historical essay]. Sankt-Petersburg: Typ.M. Stasiulevycha, 217 p. [in Russian].

Pamiatnaia knizhka Kievskogo uchebnogo okruga [Memorable book of Kiev educational district], (1890). Ch.U. Poltavskaia hubernyia. Kyiv., 1890, 245 p. [in Russian].

Pavlovskiy, I. F. (1914 a). Nemetskye kolonyy v Poltavskoi hubernyy XIX st. (1808 - 1867) (po arkhyvnym dannym) [German colonies in the Poltava province of the XIXth century $(1808-1867)$ (according to archival data)]. Trudy Poltavskoi uchenoi arkhyvnoi komyssyy. Poltava, (10), 97-215. [in Russian].

Pavlovskiy, I. F. (1906). Statisticheskiye svedeniya o Poltavskoy gubernii sto let nazad [Statistical information about Poltava province a hundred years ago.]. Trudy Poltavskoy uchenoy arkhivnoy komissii, (2), 234 p. [in Russian].

Pavlovskiy, I. F. (1914 b). Ocherk deyatelnosti malorossiyskogo general-gubernatora knyazya A.B. Kurakina (1802-1808 gg.): po arkhivnym dannym s risunkami [Essay on the activities of the Governor-General of Malorossiya, Duke A. B. Kurakin (1802 - 1808): according to archival data, with drawings.]. Poltava: T-vo Pechatnogo Dela. 31 p. [in Russian].

Poltava Governorate. URL: https://en.wikipedia.org/wiki/Poltava_Governorate [in English].

Pysarevskyi, H. T. (1909). K istorii inostrannoi kolonyzatsii $v$ Rossii $[$ To the history of foreign colonization in Russia]. Moscow: Pechatnia A. Y. Snehyrevoi, 1909, 346 p. [in Russian].

Shandra, V. (2001). Malorosiiske heneral-hubernatorstvo 1802 - 1856: funktsii, struktura, arkhiv [Malorosiyske Governor-General 1802 - 1856: functions, structure, archive]. Kyiv: Vyd-nia Derzh. komitetu arkhiviv Ukrainy, 356 p. [in Ukrainian].

Shvaika, I. O. (2018). Vzaiemovidnosyny nimetskykh kolonistiv ta ukrainskoho naselennia (kinets XVIII - 20-ti roky XX stolittia) [Relations between the German colonists and the Ukrainian population (end of the 18th - 20th years of the 20th century)] (Candidate's thesis). Kharkiv, 256 p. [in Ukrainian].

Shvaika, I. O., (2016). Ekonomichni vzaiemovidnosyny nimetskykh kolonistiv z ukrainskym naselenniam u XIX stolitti [Economic relationship between the German colonists and the Ukrainian 
population in the XIX century]. Zbirnyk naukovykh prats. Istoriia ta heohrafiia. Kharkiv, (53), 16-21. [in Ukrainian].

Volovyk, V., \& Yatsiuk, V. (2017). Nimetski silski etnokulturni landshafty Podillia XIX pochatku XX storichchia [German rural ethnocultural landscapes of Podillya of the XIXth and early XXth centuries], Visnyk Kyivskoho natsionalnoho universytetu imeni Tarasa Shevchenka, seriia «Heohrafiia», Kyiv, (3), 103-107. DOI: http://doi.org/10.17721/1728-2721.2017.68.19 [in Ukrainian].

Zghurskyi, O. Nimetskyi ostrivets u Poltavi [German islet in Poltava]. URL: https://poltava.to/ news/7646/ [in Ukrainian].

Zhuk, V. N. (2006). Doleiu pov'iazani z Ukrainoiu. Narysy z istorii nimetskykh kolonistiv na Poltavshchyni, pro doliu yikh nashchadkiv $i$ vidrodzhennia nimetskykh tovarystv $u$ krai [The fate is connected with Ukraine. Essays on the history of the German colonists in Poltava region, the fate of their descendants and the revival of German societies in the province]. Poltava: Dyvosvit, 330 p. [in Ukrainian].

The article was received on February 22, 2019. Article recommended for publishing 10/06/2019. 